\title{
REVOLVING CAPITAL IN STOCK COOPERATIVE CORPORATIONS
}

\author{
Chardes E. Nieman*
}

Most of the older cooperative corporations originally were organized with capital structures which differed very little from those of other business corporations. They usually were organized as corporations with capital stock. Typically, they issued only common stock which was divided into shares having a substantial par value, most frequently $\$$ roo.

Today, a large and increasing number of cooperatives are organized as nonstock, membership corporations with little or no permanent capital, and-even in stock cooperatives-the trend is toward decreasing the par value of shares, decreasing the proportion of permanent capital, and increasing the proportion of temporary or interim capital. These changes in the financial structures of typical cooperatives reflect the growing realization of the distinctive nature of the capital required by cooperatives, but raise interesting questions of law.

\section{Interim Character of Cooperative Capttal}

There is a growing realization that the capital of a cooperative, so far as the permanency or impermanency of the shares or other units of the capital is concerned, is essentially different from the capital of other business corporations. Corporate capital ordinarily represents a permanent investment for the purpose of producing a recurring income to the investor. The shareholder does not expect that the capital which he contributed will be returned to him until dissolution. $\mathrm{He}$ understands that, prior to dissolution, he can recover the amount of his contribution, more or less, only by selling and transferring his shares to a purchaser which sometimes may be, but ordinarily is not, the corporation. A cooperative's capital, however, more often represents essentially a loan or temporary contribution by its patrons to finance certain economic services for them. The patron-member or patron-shareholder expects that the capital which he contributes will be returned to him prior to dissolution, but not until his own and other patrons' subsequent contributions to capital render his earlier contribution unnecessary to finance the cooperative's facilities and operations. He does not expect to wait until dissolution,

- A.B. I928, Beloit College; LL.B. I937, University of Wisconsin. Member of firm of Melrin and Nieman, Minneapolis, Minnesota. Professor of Law, University of Minnesota. Chairman, Committee on Financial Structure of Cooperatives, Section of Corporation Law, American Bar Association. Member, Legal and Tax Committee, National Council of Farmer Cooperatives. Lecturer, St. Paul College of L2w, 1939-1948. Author, ImITATION COOPERATtVes (I945); contributor to periodicals. 
and he knows that his shares are not readily salable. ${ }^{1}$ He looks to the cooperative to return his capital contributions to him if, and as soon as, it can do so.

The temporary or interim character of a cooperative's capital was most apparent, but no more real, in early, informal cooperative activities which were carried on intermittently through unincorporated and temporary organizations. That characteristic of a cooperative's capital is less apparent, but just as real, in modern cooperative activities which are continuously conducted through incorporated entities having an existence which is perpetual or for a substantial number of years.

When, more than a century ago, a group of Ohio farmers joined together to ship their cattle to market at Pittsburgh, ${ }^{2}$ each of them presumably furnished his share of the cattle, wagons, and equipment which were the "capital" for the expedition; and each participant's "capital" was returned to him upon the complation of the project. The horses, wagons, machinery, and labor required for barn raisings or threshing were furnished by the participants, and were returned to them after each job or threshing season. Each participant ceased to provide such capital, and capital previously furnished was returned to him, when he ceased farming and, thus, no longer had need for the barn-raising or threshing services and equipment of his neighbors. In such informal, cooperative enterprises, the temporary nature of the capital employed was plain.

As cooperatives developed into more permanent enterprises for more continuous furnishing of services, their patrons no longer took their "capital" home with them after each transaction. Rather, they would leave their capital contributions in the continuing activity, but it does not necessarily follow that they intended to leave their capital in the enterprise permanently. However, the economic necessity for incorporating cooperative activities, coupled with the fact that incorporation at one time was possible only under statutes designed for non-cooperative business corporations to which capital was permanently contributed, fostered the assumption that capital contributed to a cooperative corporation was irretrievably dedicated to the corporate purposes until dissolution, as in the case of other business corporations.

\section{Early Cooperattve Statutes}

The first incorporated cooperatives were formed under statutes which had not been enacted specifically for the incorporation of cooperatives. Those statutes contemplated corporate capital divided into shares of stock. Corporate stock was not indebtedness, and the shareholders had no right to a return of their capital until dissolution.

The first cooperative statutes ${ }^{3}$ were intended to make it plain that the conduct

\footnotetext{
${ }^{1}$ Iimitations on dividends and voting power and restrictions on transferability of shares in a cooperative definitely tend to limit their marketability.

${ }^{2}$ Sec Eowin G. Nourse, The Legal. Status of Agricultural Cooperation 25 et seq. (1927).

8 The first cooperative corporation statute was enacted in Michigan in 1865 . Laws of Michigan, 1865, Act No. 288. The second was passed in Massachusetts in r866. Acts of the General Court of Massachusetts, c. 290, 1866. Somewhat similar statutes were enacted in Pennsylvania in 1868 , Minnesota in 1870 , and Connecticut in 1875 .
} 
of a business on a cooperative basis was an authorized corporate purpose. They made little or no provision for the peculiar capital requirements of cooperatives. While they expressly authorized the formation of cooperative corporations, the capital requirements were still spelled out in the general corporation laws. ${ }^{4}$ Consequently, cooperative corporations were formed with capital evidenced by shares of stock. Those early cooperative corporations had capital structures which, except for the adequacy or inadequacy of the aggregate amount of capital, bore little or no relationship to a cooperative's particular capital requirements. This was the only kind of capital structure which it was possible for an incorporated cooperative to have under such statutes. There ever since has been a trial-and-error effort to develop for cooperatives a kind of capital more adequately suited to their peculiar needs and still within the corporate form.

\section{Revolving Captital in Non-Stock Cooperatives ${ }^{6}$}

The non-stock membership cooperative corporation evolved from a growing realization that shares of capital stock were not well suited to the capital requirements of cooperatives. ${ }^{6}$ Such cooperatives acquired much of their initial capital from membership fees which, originally, represented permanent capital. As memberships came to be regarded as non-transferable, the permanency of the capital which they represented was relaxed. Provision frequently was made for the return of a member's share of the capital upon the termination of his membership. The risk to the cooperative's financial integrity in the event that a substantial number of members should withdraw and demand the return of their membership capital at the same time required modification of the right to demand a return of membership capital promptly upon termination of membership. Provision was made to suspend the rights and privileges of membership or to retain the member's share of the capital until such time as the cooperative should be financially able to pay it out without undue prejudice to other members or creditors. The problems incident to the existence of permanent capital, even membership capital repayable upon termination or suspension of membership or reasonably soon thereafter, eventually were met by the creation of a new kind of temporary or interim capital which has now become quite common, although peculiar to cooperatives-that is, revolving-fund capital. ${ }^{7}$

- For example, the New Jersey Act of I875 merely permitted cooperative stores to be incorporated under the general corporation law of 1849 . See Nourse, op. cit. supra note 2, c. III.

$\checkmark$ The legality of the revolving plan of financing non-stock cooperatives has been judicially recognized. L. S. Hutbert, Legal Phases of Cooperative Associations 278 and cases cited (Farm Credit Administration, United States Department of Agriculture, Bull. No. 50, 1942.)

- See Nourse, op. cit. supra note 2, c. III (The Emergence of the Non-Stock Association).

"One type of revolving-capital plan (based on accumulations of "retains" rather than net patronage margins) is described in Reinert v. California Almond Growers Exchange, 9 Cal. 2d 181, 63 P. $2 \mathrm{~d}$ 19x (1937), where the court discussed the right of a withdrawing member to his share of the revolvingfund capital. For discussions of revolving capital generally, cf. Frank Evans and E. A. Stokdyk, The Law of Agriculturar. Co-operative Marketing I73 (1937); Hulbert, op. cit. supta note 4, at 276 et seq.; Israez Packel, The Law of the Organization and Operation of Cooperatives 180-18 I (2d ed. 1947); Sanders, Organizing a Farmers' Cooperative (Farm Credit Administration Circular C-108, 1939). 
The revolving-fund plan "has been likened to a water wheel, picking up water, using it to create the power that turns the mill machinery, and returning the water to the millstream." 8 As the margins which result from the cooperative's business operations become payable to its patrons, the patrons contribute or lend their respective shares of such margins ${ }^{\theta}$ to the cooperative and receive therefor credits in a fund which is used to finance the association's facilities and operations. When the fund becomes adequate for that purpose, it is maintained at that level ${ }^{10}$ by continuing to receive new contributions ${ }^{11}$ from current patrons each year and, to the extent that the new contributions increase the fund above the amount of capital needed, the excess is returned to the patrons who made the earliest contributions. In that way, the capital contributed to the fund in prior years is returned to the contributors in the order in which their contributions were made, and without waiting for the dissolution of the corporation. But the return of the earlier contributions does not reduce the aggregate capital in the fund below the association's needs, and neither creditors nor other contributors are prejudiced by the withdrawals, because no withdrawals are made until capital needed to replace them is contributed. Moreover, the capital employed in the association is thus furnished by its current patrons and in proportion to the use which they make of its facilities and services, that is, according to their patronage.

\section{Non-Stock Revolving Funds in Stock Cooperatives}

The success of revolving capital in non-stock membership cooperatives and the difficulties which stock cooperatives experienced with capital stock ${ }^{12}$ persuaded

${ }^{8}$ Stokdyk, Financting Farmers' Cooperatives 6 (Farm Credit Administration Circular E-20, 1937).

Some revolving funds are accumulated by contributions which each patron has authorized the cooperative to retain from the gross proceeds of its sale of the patron's produce at the rate of so many cents for each crate, box, bushel, or other unit of produce. See note 7 supra.

${ }^{10}$ It ordinarily is not contemplated that the balance of the fund necessarily will remain constant. The fund may be increased as the business expands and additional capital is required. On the other hand, it is not contemplated that the fund will continue to accumulate forever; rather it is expected to "revolve" as new contributions maintain the fund at an adequate level. Cf. note I 4 infra.

11 For convenience, the sums added to the revolving fund are uniformly referred to herein as "contributions" and the patrons or others who. furnish such additions to the fund are uniformly referred to as "contributors." Those terms should not preclude the understanding that such amounts may actually be "loans," rather than donations, and such persons "creditors," where the contract pursuant to which such additions are made manifests an intention to create a debtor-creditor relationship. Moreover, the use of the terms "contributions" and "contributors" should not preclude the understanding that such additions, in contrast, to contributions to capital stock, must be repaid at a fixed or determinable future time prior to dissolution.

${ }^{12}$ Cooperative principle requires that the business be principally owned and controlled by the patrons it serves rather than by non-patron investors. Experience has demonstrated that, to be successful, cooperative practice must conform to that cooperative principle. Otherwise a conflict of interest develops between the patrons and investors. The patrons will be interested primarily in obtaining satisfactory service and maximum returns on their products marketed or maximum savings on their supplies purchased through the cooperative; they look to their individual farming businesses to produce their direct profits. Investors, on the other hand, naturally and legitimately look for maximum profits directly from their investments in the cooperative. In associations in which shares of capital stock originally were issued to farmer-patrons but without adequate provision for revolving or reacquiring such shares, the shares gradually passed into the hands of non-patron shareholders by reason of the retirement or death of the original patron-shareholders. In such cases, a sharp conflict of interest 
many stock cooperatives to try to adapt the revolving capital plan to their own associations. Sometimes a revolving fund has been established in addition to the capital stock and without attempting to revolve the share capital. Where that is done, little legal difficulty may be expected if the rights and responsibilities of both the corporation and the contributors with respect to the fund are carefully spelled out in the articles of incorporation, by-laws, or other contract with the patrons who contribute their patronage margins to the fund.

Where the contributor's contract makes it clear that the fund represents borrowed money which is repayable at some ascertainable, though presently indefinite, time in the future, little question of the corporate authority to create and maintain the fund can be raised. ${ }^{13}$ Such a fund is essentially similar to an ordinary business corporation's funded debt with serial maturities, although the maturities of the cooperative revolving-fund interests are more closely geared to the actual results of the cooperative's future business operations.

Frequently, however, the contributor's interest in the fund is intended to be, or to include at least an element of, an owner's interest as distinguished from a creditor's interest, but is also intended to be something different from a shareholder's interest. In such cases, some question may be raised concerning the corporation's authority to have capital which is neither payable to creditors at a fixed maturity date nor irretrievably contributed by shareholders. It conceivably may be suggested that the statute authorizing the incorporation of the cooperative with capital stock does not contemplate and, therefore, does not authorize the creation of a kind of capital which is neither indebtedness, as other liabilities are, nor an ownership interest in the corporation such as shareholders have.

The answer to that suggestion, it is submitted, is that the contributors to the revolving fund have no rights which could not separately be lawfully granted to either creditors or shareholders. If so, the fact that the combination of rights granted to contributors to the revolving fund may be somewhat unusual does not demonstrate that the creation of such rights is unlawful, nor that the corporation is not authorized to enter into a contract creating such rights. For example, it is lawful for a corporation to borrow money and to use it for capital purposes until maturity. Likewise, it is lawful for a corporation to receive contributions to its capital which the contributors cannot require the corporation to repay at any specific time but which, a right to redeem having been reserved, the corporation may return when it determines to do so. So, a revolving-fund contract may grant the contributor a right, like the right of creditors, to have his money returned to him, but at a time, as in the case of redeemable shares of stock, to be determined by the corporation in the light of its then existing financial ability and capital require-

has arisen concerning the rate of dividends to be paid on the share capital, and considerable handicaps through loss of tax exemptions and favorable credit facilities have resulted from too large a proportion of shares in the hands of non-farmers or non-patrons. $C f$. notes 15 and 16 infra.

18 The authority of private corporations to borrow money for proper corporate purposes is well established. Fletcher, Cyclopedis of the Law of Private Corporatjons \$261o (Perm. ed., i932). 
ments. ${ }^{14}$ Consequently, it is submitted that so long as the separate rights flowing from the revolving-fund contract are rights which the law has authorized corporations to grant to their creditors or shareholders, or both, the authority to enter into a contract granting such rights in new combinations should not be denied in the absence of clear statutory prohibition or compelling reasons of public policy.

\section{Revolving Capital Stock}

More serious legal questions may arise, however, where a stock cooperative undertakes to adopt the revolving-capital plan by revolving its shares of stock instead of creating a separate revolving fund. Revolving shares of stock may take various forms. If the association has only one class of stock authorized, the amounts which current patrons contribute to capital from their current patronage margins may be the consideration for issuing shares of such stock to the current patrons, and the funds thus received are used to repurchase or redeem the shares which have been longest outstanding. Other associations, which have two or more classes of stock authorized, may issue one class of stock in consideration of the patrons' contributing their patronage margins to capital and use the funds thus received to repurchase or redeem shares of the same class which have been longest outstanding, thus revolving that class of stock while the other class remains relatively constant and permanent.

Associations which have only one class of voting common stock authorized may encounter collateral difficulties in attempting to revolve such shares. To qualify for exemption from corporate income taxes ${ }^{15}$ or to be eligible to borrow from the Banks for Cooperatives, ${ }^{16}$ substantially all of the voting stock must be held by farmers. Thus, an association which has no non-voting stock authorized and which tries to revolve its voting stock may be confronted with the choice of either issuing voting shares to ineligible patrons and thus destroying its own eligibility for tax exemption or borrowing privileges, or else paying patronage margins to ineligible, non-member patrons in cash and thus freeing them from any responsibility for contributing to capital while member patrons alone bear the burden of furnishing the capital needed to finance the cooperative. The former alternative can produce

\footnotetext{
14 Revolving-fund contracts commonly contemplate that the cooperative, rather than the contributors, shall determine when and to what extent the fund shall revolve and contributions shall be returned to the contributors. It is submitted, however, that it commonly is the understanding of the parties (and hence their express or implied contract) that the directors of the cooperative shall make that determination in good faith and for the purposes for which the cooperative was formed and the revolving fund created. If so, then the contributors' right to have the fund revolve and their contributions returned to them means that the directors cannot capriciously or arbitrarily refuse to return the contributions. Nor should the directors be able to refuse to do so in bad faith, or for personal reasons, or for other purposes having no reasonable relation to the corporate purposes and the objects for which the fund was created. The directors' determination is a matter calling for the bona fide exercise of business judgment, against an abuse of which the contributors should have a judicial remedy. Cf. Ford v. Dodge Motor Company, 204 Mich. 459, 170 N. W. 668 (1919) and discussion therein of limitations on directors' discretion in the matter of declaring dividends on stock in a corporation for profit.

${ }_{15} 26$ U.S.C.A. \$IOI (I2); U. S. Treas. Reg. III, \$29.10I(I2)-I (I943).

${ }^{16} 12$ U.S.C.A. $\$$ II $34 \mathrm{C}$, II $4 \mathrm{Ij}$.
} 
serious consequences in jurisdictions where shares issued to persons ineligible to hold them are void; the latter alternative is plainly unfair to the shareholder-patrons. Consequently, an attempt to revolve shares in an association which has only one class of shares authorized can produce real legal complications wholly aside from any questions as to the legality of revolving the shares.

Cooperatives which have two classes of stock authorized, one a voting stock and the other a non-voting stock-either common or preferred-frequently contract with their patrons to pay patronage margins entirely in non-voting stock. Where only the non-voting shares are revolved, the difficulties suggested in the preceding paragraph are avoided. The importance of having as many patrons as possible hold membership or voting shares has persuaded some cooperatives, with both voting and non-voting shares authorized, to contract with their patrons that patronage margins payable to eligible non-member patrons will, to the extent of the par value of one or more voting shares, be paid in voting shares, and the remainder of such patrons' margins and the total margins due member-patrons will be paid in nonvoting shares. In that way, the greatest possible number of eligible non-member patrons are brought into membership in the quickest possible time, and the dangers inherent in transacting too large a proportion of the association's business with non-member patrons are minimized. Where patronage margins are paid to eligible non-member patrons in voting shares and all margins payable to member-patrons and ineligible non-member patrons are paid in non-voting shares, the non-voting shares may be revolved. In that way, the non-member patrons ratably furnish capital on the same basis as member-patrons, and the fairness of that basis is apparent.

\section{Revolving Stock by Redemption of Shares}

Regardless, however, of which of the above suggested plans for revolving-capital stock is adopted, there are certain very real legal hazards which should be recognized. The right to redeem shares of stock does not exist in the absence of express authority. ${ }^{17}$ Consequently, a plan of revolving shares of stock cannot be inaugurated in an existing cooperative with any assurance that the shares outstanding when the plan is adopted will actually be surrendered to the association when it undertakes to redeem them. Numerous stock associations already have experienced difficulty in persuading non-patron shareholders to relinquish their shares, and that problem has become acute in many associations where the shares held by non-patrons are voting shares free from any right of redemption in the corporation. In such cases, the association can acquire such shares, if at all, only by repurchasing them instead of redeeming them. Aside from practical difficulties in arriving at a purchase price which will persuade the holder to sell and which will be fair to existing shareholders and creditors, there are jurisdictions in which the repurchase of shares by noncooperative corporations has been held to be unauthorized or prohibited, or so hedged about with limitations designed for the protection of creditors and existing

${ }^{17}$ FLETCHER, op. cit. supra note 13, \$\$5147, 5309 . 
shareholders that repurchase by a cooperative might be unlawful or at least impracticable. ${ }^{18}$

Whenever a plan of revolving shares is instituted, care must be exercised to determine whether the revolving process is going to proceed in the future by way of redemption or repurchase of subsequently issued shares; and whichever procedure is to be followed, adequate provision must be inserted in the articles or by-laws to insure that subsequently issued shares may be reacquired when the time to "revolve" such shares arrives. It should be made clear whether or not the shares reacquired by the corporation are being retired or not. If they are retired so that they cannot again be reissued, there is a real danger that the authorized capital may soon be exhausted even though the shares outstanding at any one time do not approach the limits of the authorized capital. It may not be clear whether redemption of shares necessarily involves their retirement. It is preferable that the revolving process proceed by repurchase of shares rather than by redemption where redemption may involve automatic retirement of the shares redeemed and thus render them unavailable for reissuance.

\section{Revolving Stock by Repurchase of Shares}

Repurchase of shares is a branch of corporation law in which both the courts and legislatures have produced a mystifying maze of contradictory prohibitions and limitations. As in England, ${ }^{10}$ there are American states in which it is held that corporations are without authority to repurchase shares. ${ }^{20}$ In such jurisdictions, a revolving-capital plan cannot be adopted by a stock cooperative if the prohibitions against repurchase of shares applicable to non-cooperative corporations are blindly applied to cooperative corporations without discriminating understanding of the reasons which have produced those prohibitions in general business corporation law and without understanding of the cooperative principles and practices which may render the reasons, and hence properly should render the prohibitions, inapplicable to the repurchase of shares by a cooperative.

The view that corporations must not repurchase their own shares is usually based on four grounds. First, a corporation cannot increase or diminish the amount of its capital stock as fixed by the legislature. Second, repurchase of shares works a fraud on creditors. Third, such transactions work a fraud on existing shareholders. Fourth, repurchase of shares is foreign to the purposes for which the corporation was created and, therefore, a violation of its charter and an unauthorized diversion of its funds. ${ }^{21}$ Before the repurchase of shares by a cooperative is judicially forbidden, courts and lawyers should examine and understand not only the above grounds usually asserted for prohibiting repurchase of shares by noncooperative business corporations, but also cooperative principles and practices. ${ }^{23}$

${ }^{18}$ Id. $\$ 52845-286 \mathrm{r}$.

${ }^{20}$ Trevor v. Whitworth, L. R. 12 App. Cas. 409 (1887).

${ }^{20}$ FLETCHER, op. cit. supra note $13, \$ 2847$ and cases cited.

${ }^{23}$ See Whitney v. Farmers Co-op. Grain Co., 110 Neb. 157, 193 N. W. 103, 104 (1923), where the nature and purpose of the cooperative defendant were considered in sustaining a by-law requiring it 
Under almost all modern cooperative corporation statutes, the legislature does not establish any fixed amount of capital stock for the association; rather, the incorporators originally, and shareholders subsequently, establish in the articles of incorporation a maximum authorized capital beyond which shares shall not be issued. It is a common provision to prohibit the reduction of capital below a stated percentage of the authorized capital. However, such minimum and maximum limits should not be construed to prevent the operation of a revolving-capital plan so long as the actual capital never falls below the statutory minimum nor exceeds the maximum. In any event, the first above-stated reason for prohibiting repurchase of shares should not apply where, as in the case of a cooperative's revolving capital, the shares are repurchased and reissued rather than retired.

The revolving-capital plan properly should not be permitted to work a fraud on creditors. However, that obviously is not a sound reason for prohibiting the repurchase of shares where there are no creditors or the creditors have expressly or impliedly consented. In view of the actual practices of cooperatives, their creditors may extend credit with knowledge of the revolving-capital plan and expressly or impliedly consent to it. In any event, it would seem that the rights of creditors are adequately protected if the amount of stock repurchased in any given fiscal period does not materially exceed the amount of new capital contributed to the corporation in the same period by current patrons from their current patronage margins, and, certainly, it is the normal practice of cooperatives to gauge the amount of stock to be repurchased from old patrons by the amount issued to current patrons from their current patronage margins.

The protection of existing shareholders likewise is not a persuasive reason for prohibiting the repurchase of its own shares by a cooperative on a revolving-capital plan. The shareholders acquire their shares as a part of the revolving-capital plan and, as a matter of actual fact and genuine understanding, may expressly or impliedly contract that the association may repurchase its shares, at least to the extent that new capital is acquired from current patrons and current patronage margins.

Finally, the argument that the repurchase of shares is foreign to the purposes for which the corporation was chartered, which is the real basis for the prohibition against repurchase of shares by a non-cooperative business corporation, ${ }^{23}$ loses all of its force when applied to a cooperative on a revolving-capital plan. The trend toward revolving-capital plans is so marked, and the revolving-capital plan by which current patrons furnish the capital necessary to finance the facilities and services which they use as patrons is so thoroughly in accord with sound cooperative principles and practices, that it is to be hoped that courts and lawyers will not blindly apply to cooperatives this reasoning, which is so utterly foreign to the cooperative plan of doing business for which a cooperative corporation is chartered.

to repurchase its shares from the plaintiff-shareholder upon his removal from the community; Chaffee v. Farmers Co-operative Elevator Co., 39 N. D. 585,168 N. W. 616 (1918), where restriction on transfer of shares was sustained by reason of the cooperative character of the defendant.

${ }^{18}$ FLETCHER, op. cit. supra note 13,52847 . 


\section{Application of Business Corporation Law to Cooperatives}

The entire field of cooperative corporation law is so relatively new, ${ }^{24}$ the basic principles of the cooperative plan are so fundamentally different from those of corporations for profit, $^{25}$ and the temporary or interim character of the capital required for proper functioning of a cooperative is so different from the permanent share capital of other business corporations, that even well established concepts in the field of business corporation law cannot safely be applied to cooperative corporations without careful understanding of the reasons underlying those principles and the applicability or inapplicability of those reasons to cooperatives. The fable of the three blind men's impressions of an elephant holds a pointed moral for judges and lawyers approaching the problems of cooperative corporation law and, particularly, the problems of financial structure and operation of cooperatives. Revolving capital cannot be assumed to result from the creation of either an exclusively debtor-creditor relationship or an exclusively corporation-shareholder relationship. Rather it involves a blending of certain elements of both, and frequently something new has been added as well. The resultant product is sui generis. In the long run, the public interest will best be served by thorough, patient, and understanding comprehension of what participants in a cooperative enterprise are trying to achieve, rather than by unwarranted assumption that new legal relationships arising from cooperative business transactions and organizations must be neatly and quickly, albeit somewhat forcibly, classified according to preexisting legal concepts developed under different conditions for different purposes in different kinds of transactions and organizations.

\footnotetext{
24 See discussions of development of cooperative corporation law in Evans aND STOKDYR, op. cit. supra note 7, at I8 et seq.; NouRse, op. cit. supra note 2, at 25-115. "The legal profession has done comparatively little in the way of research and legislative work on cooperatives." PACKEL, op. cit. supra note 7 , at 2 .

${ }^{25}$ See Evans and StokdyK, op. cit. supra note 7, at 3-5; HuLbert, op. cit. supra note 7, at I-5.
} 